\title{
The Rise and Expansion of Christianity in the First Three Centuries of the Common Era
}

\author{
Ed. by Clare K. Rothschild and Jens Schröter \\ [Die Entstehung und Ausbreitung des Christentums in den ersten drei Jahrhunderten.]
}

The Rise and Expansion of Christianity in the First Three Centuries of the Common Era

$$
\text { Edited by }
$$
CLARE K. ROTHSCHLD and JENS SCHRÖTER

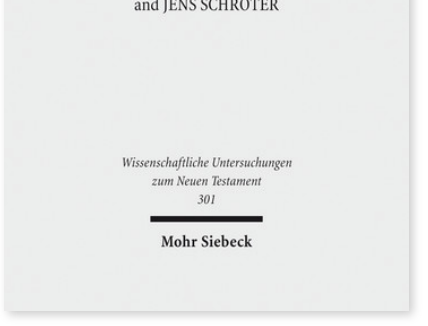

2013. IX, 543 Seiten. WUNT I 301

ISBN 978-3-16-152285-7 eBook PDF 159,00€ ISBN 978-3-16-152249-9 Leinen $159,00 €$
Veröffentlicht auf Englisch.

Die hier versammelten Aufsätze basieren zum Teil auf einem Symposium, das im Juli 2010 an der Humboldt-Universität zu Berlin stattfand. Für den vorliegenden Band wurden sie um etliche Beiträge ergänzt, die weitere wichtige Aspekte zu dem Thema beisteuern. Ziel der Tagung war es, die Entstehung und erstaunlich schnelle Ausbreitung des Christentums in den ersten drei Jahrhunderten zu beleuchten. Für dieses überaus spannende Thema der Erforschung des antiken Christentums drängte sich Berlin als Tagungsort geradezu auf. Adolf von Harnack hat als Professor an der damaligen Friedrich-WilhelmsUniversität (der heutigen Humboldt-Universität) zu Berlin am Beginn des 20. Jahrhunderts die wohl bekannteste umfassende Darstellung zu diesem Thema vorgelegt: »Die Mission und Ausbreitung des Christentums in den ersten drei Jahrhunderten« (1902). Seither sind durch vielfältige Forschungen auf den Gebieten der Archäologie, der Epigraphik, der Interpretation neutestamentlicher Texte sowie der apokryphen Texte des antiken Christentums neue Perspektiven auf die Geschichte des antiken Christentums entwickelt worden. Zudem haben Autoren wie Ramsey MacMullen und Rodney Stark das Interesse an einer umfassenden Konzeption des Themas wieder belebt. Die Aufsätze im vorliegenden Band spiegeln die Vielfalt gegenwärtiger Forschungsansätze wider. Sie beschäftigen sich mit dem kulturellen Milieu und wichtigen Texten, um daran das weite Feld der Entstehung und Ausbreitung des antiken Christentums zu beleuchten. Behandelt werden u.a. Paulus, Jesus und die Evangelien, weitere Texte des Neuen Testaments, apokryphe Apostelakten sowie Facetten der Ausbreitung des Christentums im zweiten und dritten Jahrhundert.

Inhaltsübersicht

Clare K. Rothschild: Introduction I. Cultural Milieu James Carleton Paget: Hellenistic and Early Roman Period Jewish Missionary Efforts in the Diaspora - William Horbury: Jewish and Christian Origins in Roman Africa II. First Century Developments: From Galilee to Asia MinorJesus and the Gospels Jürgen K. Zangenberg: From the Galilean Jesus to the Galilean Silence: Earliest Christianity in the Galilee until the Fourth Century CE - Thomas Söding: Die Saat des Evangeliums. Vor- und nachösterliche Mission im Markusevangelium - Matthias Konradt: Die Ausrichtung der Mission im Matthäusevangelium und die Entwicklung zur universalen Kirche. Überlegungen zum Standort des Matthäusevangeliums in der Entwicklung des Christentums Paul Wayne Meeks: From Jerusalem to Illyricum, Rome to Spain: The World of Paul's Missionary Imagination - James D.G. Dunn: The Rise and Expansion of Christianity in the First Three Centuries C.E.: Why and How Did Embryonic Christianity Expand Beyond the Jewish People? - Michael Wolter: Jesus bei Paulus Other Trajectories Jörg Frey: Von Paulus zu Johannes: Die Diversität »christlicher « Gemeindekreise und die »Trennungsprozesse« zwischen der

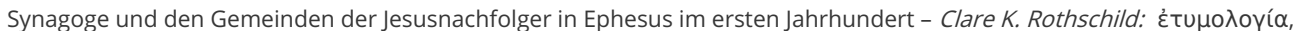
dramatis personae, and the Lukan Invention of an Early Christian Prosopography - Jan Dochhorn: Ist die Apokalypse des Johannes ein Text des Christentums der Asia? Einige Überlegungen - Enno Edzard Popkes: Antike christliche Apokryphen als Spiegel frühchristlicher Identitätsbildungsprozesse: Beobachtungen am Beispiel kanonischer und außerkanonischer Haltungen zum Verzehr von »Götzenopferfleisch« - Richard I. Pervo: The Hospitality of Onesiphorus: Missionary Styles and Support in the Acts of Paul - Janet E. Spittler: Christianity at the Edges: Representations of the Ends of the Earth in the Apocryphal Acts of the Apostles - Trevor Thompson: Claiming Ephesus: Pauline Legacy in the Acts of John III. Christianity between »Orthodoxy, « »Heresy, « and Paganism in the Second and Third Centuries Candida R. Moss: Polycarphilia: The Martyrdom of Polycarp and the Origins and Spread of Martyrdom - Ismo Dunderberg: Early Christian Critics of Martyrdom Karen L. King: Theologies and Mission Practices among the so-called »Heretics« - Jörg Ulrich: Die Begegnung von Christen und Heiden im zweiten (und dritten) Jahrhundert Jens Schröter: Epilogue

Clare K. Rothschild Born 1964; 1986 BA University of California, Berkeley; 1992 MTS Harvard University; 2003 PhD University of Chicago; 2006 postdoctoral fellow Alexander von Humboldt Foundation at Ludwig-Maximilians-Universität München; currently Professor of Scripture, Department of Theology, Lewis University (USA) and Professor Extraordinary, Department Ancient Studies at Stellenbosch University (South Africa).

https://orcid.org/0000-0002-6572-8604

Jens Schröter Geboren 1961; 1992 Promotion; 1996 Habilitation; Professur für Exegese und Theologie des Neuen Testaments sowie die antiken christlichen Apokryphen an der Theologischen Fakultät der Humboldt-Universität zu Berlin. https://orcid.org/0000-0001-7878-2709

Jetzt bestellen:

https://mohrsiebeck.com/buch/the-rise-and-expansion-of-christianity-in-the-first-three-centuries-of-the-common-era9783161522857?no_cache=1

order@mohrsiebeck.com

Telefon: +49 (0)7071-923-17

Telefax: +49(0)7071-51104 